\section{Effects of Dietary Level of Calcium on Body Proportion and Nutritional Value of African Giant Snail (Archacha- tina marginata)}

\author{
Tchakounte Frank Maël ${ }^{1 *}$, Kana Jean Raphaël ${ }^{1}$, Azine \\ Pascaline Ciza², Meffowoet Chekam Prisca' ${ }^{1}$ and Djuidje \\ Verdiane Paule ${ }^{1}$
}

${ }^{1}$ Animal Production and Nutrition Research Unit, Department of Animal Sciences, Faculty of Agronomy and Agricultural Sciences, University of Dschang, Cameroon

${ }^{2}$ Department of Animal Production, Faculty of Agronomy and Environmental Sciences, Université Evangélique en Afrique, Democratic Republic of Congo (DRC)

\begin{abstract}
The study was designedto evaluate the effect of dietary level of calcium on meat yield and nutritional value of the African giant snail (Archachatina marginata). The snails were fed on diet containing $12 \%, 14 \%, 16 \%$ and $18 \%$ calciumfor thirty-two weeks. The results revealed that the final live body weight, the proportion of meat and shell increased with the increasing level of calcium in the ration. The highest shell yield $(36.5 \%)$ and the lowest proportion of soft tissue $(59.87 \%)$ were recorded with the highest content of calcium (18\%). The highest viscera yield was recorded with the lowest calcium level $(24.48 \%)$, while the proportion of the shell increased with increasing level of calcium $\left(R^{2}=0.9752\right)$. The highest meat yield $(45.70 \%)$ was achieved with $16 \%$ calcium, while the lowest meat $(38.47 \%)$ and the highest shell yield (36.50\%) were achieved with $18 \%$ calcium. Meat content in proteins increased $(p<0.05)$ with increasing level of calcium from $45.85,50.52,55.22$ to $57.30 \%$ respectively with $12 \%$,
\end{abstract}

*Corresponding author: Tchakounte Frank Maël, Animal Production and Nutrition Research Unit, Department of Animal Sciences, Faculty of Agronomy and Agricultural Sciences, University of Dschang, Cameroon, Tel: +237 676034685 ; E-mail: frank.tchakounte@yahoo.com

Citation: Maël TF, Raphaël KJ, Ciza AP, Prisca MC, Paule DV (2019) Effects of dietary level of calcium on body proportion and nutritional value of African giant snail (Archachatina marginata). J Anim Res Vet Sci 3: 020.

Received: October 04, 2019; Accepted: November 06, 2019; Published: November 13, 2019

Copyright: @ 2019 Maël TF, et al. This is an open-access article distributed under the terms of the Creative Commons Attribution License, which permits unrestricted use, distribution, and reproduction in any medium, provided the original author and source are credited.
$14 \%, 16 \%$ and $18 \%$ calcium. Meat content in fat and carbohydrates significantly $(p<0.05)$ decreased with increasing level of dietary calcium. Thevariation of calcium level had no significant effect $(p>0.05)$ on the mineral composition of the shell.It was concluded that the calcium needs for a better growth, and nutritional value of Archahatina marginata is $16 \%$.

Keywords: Archachatina marginata; Calcium; Carcass yield; Nutrient content

\section{Introduction}

In Sub-saharan Africa, forest food resources provide rural households with a very important part of animal protein [1]. Among these forest resources, snails are highly appreciated for the quantity, flavour and quality of meat that they provide [2]. In fact, their flesh is an excellent source of crude protein that varies between $40 \%$ and $82.87 \%$ $[3,4]$ and contains almost all the essential amino acids, energy and minerals [3,5-7]. The flesh of snails has low fat [2] and is highly recommended for dietetics in low-fat diets [8].

The portions of meat traditionally consumed by humans represent about $1 / 3$ of the live weight of the giant snail compared with almost half of the live weight for the uneaten shell and viscera $[9,10]$. One kilogram of giant snail destined for human consumption can be recovered for almost half a kilogram of high-value animal feed (calcium and protein) [2]. Indeed, snail shell powder is used in animal feeds such as broilers and layers, small livestock and cattle as a source of calcium [11]. The shell can also be used in crop production to reduce soil acidity [12]. The results of Sika et al., [2,13] have shown that the meat yield and nutritional value of Achatina fulica was improved with the increasing level of protein in the diet. However, no in-depth study has yet been conducted on the minimum level of calcium to be included in the diet of Archachatina marginata snails to ensure better meat yield and better nutritional value. The present study was designed to evaluate the effect of dietary calcium level on the meat yield and nutritional value of the giant African snail Archachatina marginata [14].

\section{Materials and Methods}

\section{Period and site of study}

This study was conductedat the Teaching and Research Farm of the University of Dschang, Cameroon between March and October 2018. The breeding took place in bins arranged along the walls inside a building in hard closed on all sides. The average temperature in the building was $19.7^{\circ} \mathrm{C}$, the relative humidity $62.4 \%$, the temperature of the substrate $16^{\circ} \mathrm{C}$, and its humidity $84 \%$. The photoperiod was natu$\operatorname{ral}(12 \mathrm{~h} / 12 \mathrm{~h})$.

\section{Animals and experimental design}

A total of 180 snails with average weight $10.00 \pm 1.00 \mathrm{~g}$, $33.00 \pm 1.00 \mathrm{~mm}$ length and $24.00 \pm 1.00 \mathrm{~mm}$ width were randomly assigned to four experimental diets in a completely randomized design 
with 45 snails per treatment. Each group was subdivided into 5 replicates of 9 snail's eachcorresponding to a density of $75 \mathrm{snails} / \mathrm{m}^{2}$. They were collected in cocoa plantations in the Moungo subdivision (Njombé). The snails were selected based on their morphology and behavior: live weight, shell shape with no breakage, free from visible and active trauma.

The snails were raised in plastic tanks with $45 \mathrm{~cm}, 30 \mathrm{~cm}$ and $25 \mathrm{~cm}$ respectively for length, width and depth. A fine mesh ( $2 \mathrm{~mm}$ mesh) was placed above each tank to prevent snails from escaping. The substrate was made up with $10 \mathrm{~cm}$ deep white sawdust. The moisture content of the substrate was maintained above $85 \%$ by watering each tank after 2 days with $120 \mathrm{ml}$ of water. The experimental diets consisted of rations containing 12, 14, 16 and 18\% calcium (Table 1). Snails were weighed at the beginning of the trail and on a two weeks basis thereafter, for a period of eight months. Throughout the experiments trails, the snails received feed and water ad libitum every day.

\section{Carcass characteristics}

After 8 months, 6 snails from each treatment group were randomly selected, fasted for $24 \mathrm{~h}$, then marked and weighed before being euthanized by scalding (immersion in boiling water for $10 \mathrm{~min}$ ). After cooling, the soft tissues were removed from the shell and drained in a colander. Empty shells were also drained. A set of organs (foot, head, distal edge of the mantle bearing the last centimeter of the rectum and anus, pneumostome, pallial bead, distal part of the genital tract including the penile sleeve, the anterior part of the digestive tract until the first half of the crop) were separated from the rest of the visceral organs (digestive glands, gonads, albumin glands, genital tract, heart and hepatopancreas). For each snail, the weight of the edible flesh, the visceral mass and the weight of the empty shell were determined.
From these parameters, the proportions of the various parts of the body of the snails were calculated with the following formulas:

Proportion of empty shell $(\%)=$ PEs $\times 100 /$ LW

Proportion of visceral mass $(\%)=\mathrm{PVm} \times 100 / \mathrm{LW}$

Proportion of soft tissue $(\%)=\mathrm{PSt} \times 100 / \mathrm{LW}$

Proportion of edible flesh $(\%)=\operatorname{PCf} \times 100 /$ LW

PEs: Empty shell weight; LW: Live weight of the snail; PVm: Weight of the visceral mass; PSt: Soft tissue weight; PCf: Weight of edible flesh.

\section{Proximateanalysis of the flesh}

After the evaluation of the meat yield, 20 snails were samples from each treatment group, weighed and dried in a ventilated oven at $60^{\circ} \mathrm{C}$ till constant weight forproximate analysis. Dry matter, crude protein, fat content, total carbohydrates and minerals (calcium, phosphorus, potassium, magnesium and iron) were determined by the procedure described by AOAC (1990) [15]. Shell samples were collected for mineral content determination. Carbohydrates were obtained by the following formula:

Carbohydrates $(\%$ MS $)=$ Organic Matter $-($ Fat + Crude Proteins $)$

\section{Statistical analysis}

Data collected on the different parameters were submitted to oneway analysis of variance test by General Model procedure of Statistical Package for Social Science (SPSS 20.0) software. The different were tested using Duncan's multiple range's test and probability values less than 0.05 were considered as significant. The Pearson regressions established the links betweenthe growth and reproduction parameters.

\begin{tabular}{|c|c|c|c|c|}
\hline \multirow{2}{*}{ Ingredients (kg) } & \multicolumn{4}{|c|}{ Experimental diets } \\
\hline & $\mathrm{R} 1(12 \% \mathrm{Ca})$ & $\mathrm{R} 2(14 \% \mathrm{Ca})$ & $\mathrm{R} 3(16 \% \mathrm{Ca})$ & $\mathrm{R} 4(18 \% \mathrm{Ca})$ \\
\hline Maize & 15 & 15 & 18 & 20 \\
\hline Soybean cake 49 & 20 & 20 & 20 & 13.5 \\
\hline Cotton cake & 14.75 & 14.75 & 9 & 0 \\
\hline Palm kernel cake & 6 & 0 & 0 & 0 \\
\hline Fish meal & 0 & 0 & 5.5 & 17 \\
\hline Wheat bran & 12 & 5 & 0 & 0 \\
\hline Seashell & 31 & 32.5 & 37.5 & 40.5 \\
\hline Palm oil & 0.5 & 0.5 & 0.5 & 0.5 \\
\hline Salt & 0.25 & 0.25 & 0.25 & 0.25 \\
\hline Premix 0.5\% & 0.5 & 0.5 & 0.5 & 0.5 \\
\hline Agar-agar & 0 & 11.5 & 6.25 & 7.75 \\
\hline Total (kg) & 100 & 100 & 100 & 100 \\
\hline \multicolumn{5}{|c|}{ Analysed chemical composition } \\
\hline Crude protein (\%) & 18.86 & 18.93 & 19.13 & 19.21 \\
\hline Crude energy (Kcal) & 4193.00 & 4361.14 & 4315.82 & 4331.17 \\
\hline Fat (\%) & 1.12 & 2.23 & 1.48 & 2.28 \\
\hline Calcium (\%) & 11.85 & 13.57 & 16.01 & 17.76 \\
\hline Phosphorous (\%) & 0.28 & 0.26 & 0.21 & 0.23 \\
\hline Potassium (\%) & 0.17 & 0.20 & 0.30 & 0.20 \\
\hline Magnesium (\%) & 0.56 & 1.02 & 1.04 & 1.04 \\
\hline Natrium (\%) & 0.10 & 0.07 & 0.10 & 0.07 \\
\hline Iron (\%) & 0.22 & 0.25 & 0.23 & 0.25 \\
\hline
\end{tabular}

Table 1: Proximate composition of the experimental diet. 
Citation: Maël TF, Raphaël KJ, Ciza AP, Prisca MC, Paule DV (2019) Effects of dietary level of calcium on body proportion and nutritional value of African giant snail (Archachatina marginata). J Anim Res Vet Sci 3: 020.

\section{Results}

The body proportions of Archachatina marginata as affected by the calcium content of the ration is summarized in table 2 . The final live body weight, the proportion of meat and shell increased $(\mathrm{P}<0.05)$ with the increasing level of calcium in the ration until $16 \%$ but meat proportion decrease beyond $16 \%$ calcium. The soft tissue and were not affected by the level of calcium.

Table 3 summarized the carcass proportions of A. marginata as affected by the calcium content of the ration. The highest shell yield (36.5\%) and the lowest proportion of soft tissue (59.87\%) were recorded with the highest content of calcium (18\%), and the soft tissue yield decreased with increasing calcium levels $\left(\mathrm{R}^{2}=0.9829\right)$. The highest viscera yield was recorded with the lowest calcium level $(24.48 \%)$, the proportion of the shell increased with increasing level of calcium $\left(\mathrm{R}^{2}=0.9752\right)$ while the meat proportion was significantly $(\mathrm{p}<0.05)$ higher with $16 \%$ calcium as compared to all other treatments.

\section{Biochemical composition of meat}

The information's on the nutritional value of Archachatina mar- ginata meat as affected by the calcium content of the rations are presented in table 4 . The ash and protein content of snail's meat increased $\left(\mathrm{R}^{2}=0.995\right)$ with the increasing level of calcium in the ration. Fat and carbohydrates content significantly $(p<0.05)$ decreased with increasing level of dietary calcium level.

\section{Minerals content in meat}

Table 5 summarizes the mineral composition of Archachatina marginata meat as affected by dietary calcium level. The highest calcium and iron content of meat wererecorded with $16 \%$ calcium in the ration. The $\mathrm{K} ; \mathrm{Mg}$ and $\mathrm{Fe}$ content of snail meat doubled with $18 \%$ calcium in the ration as compared to ration containing $12 \%$ calcium.

\section{Minerals content in shell}

Table 6 summarizes the mineral composition of Archachatina marginata shell as affected by the graded level of calcium in the ration. The variation of the calcium level of the ration did not have any significant effect $(\mathrm{p}>0.05)$ on the mineral composition of the snail shell. However, it is noticed that calcium is the most abundant mineral in the snail shell, while the phosphorous is found in trace.

\begin{tabular}{|c|c|c|c|c|c|}
\hline \multirow{2}{*}{ Body proportions (g) } & \multicolumn{4}{|c|}{ Experimental Diets } & \multirow{2}{*}{$P$} \\
\hline & $\mathrm{R} 1(12 \% \mathrm{Ca})$ & R2 (14\%Ca) & $\mathrm{R} 3(16 \% \mathrm{Ca})$ & $\mathrm{R} 4(18 \% \mathrm{Ca})$ & \\
\hline Live weight & $40.21 \pm 1.02^{\mathrm{a}}$ & $40.95 \pm 1.93^{\mathrm{a}}$ & $44.97 \pm 3.5^{\mathrm{b}}$ & $47.99 \pm 2.00^{b}$ & 0.000 \\
\hline Shell & $10.11 \pm 0.71^{\mathrm{a}}$ & $11.33 \pm 0.81^{\mathrm{a}}$ & $13.24 \pm 0.82^{\mathrm{b}}$ & $17.52 \pm 1.38^{\mathrm{c}}$ & 0.000 \\
\hline Soft tissue & $27.01 \pm 0.80$ & $28.57 \pm 2.71$ & $29.63 \pm 3.13$ & $28.75 \pm 2.31$ & 0.411 \\
\hline Meat & $17.15 \pm 0.72^{\mathrm{a}}$ & $17.42 \pm 1.14^{\mathrm{a}}$ & $20.58 \pm 2.07^{\mathrm{b}}$ & $18.45 \pm 0.76^{\mathrm{a}}$ & 0.005 \\
\hline Visceral mass & $9.83 \pm 0.67$ & $9.82 \pm 0.90$ & $8.93 \pm 1.65$ & $9.83 \pm 1.45$ & 0.588 \\
\hline
\end{tabular}

Table 2: Effects of calcium level on body proportions of Archachatina marginata.

a, b, c: On the same line, values affected withthe same letters are not significantly different ( $>0.05)$;

R1: Diet containing 12\% calcium; R2: Diet containing 14\% calcium; R3: Diet containing 16\% calcium; R4: Diet containing $18 \%$ calcium.

\begin{tabular}{|c|c|c|c|c|c|}
\hline \multirow{2}{*}{ Carcass components (\%) } & \multicolumn{4}{|c|}{ Experimental Diets } & \multirow{2}{*}{$P$} \\
\hline & R1 $(12 \% \mathrm{Ca})$ & R2 (14\%Ca) & R3 $(16 \% \mathrm{Ca})$ & $\mathrm{R} 4(18 \% \mathrm{Ca})$ & \\
\hline Shell & $25.13 \pm 1.43^{\mathrm{a}}$ & $27.68 \pm 1.88^{\mathrm{b}}$ & $29.49 \pm 1.05^{b}$ & $36.50 \pm 2.42^{\mathrm{c}}$ & 0.000 \\
\hline Soft tissue & $67.21 \pm 2.32^{b}$ & $69.65 \pm 3.73^{\mathrm{b}}$ & $65.80 \pm 2.77^{\mathrm{b}}$ & $59.87 \pm 3.62^{\mathrm{a}}$ & 0.001 \\
\hline Meat & $42.66 \pm 1.55^{\mathrm{b}}$ & $42.51 \pm 2.60^{\mathrm{b}}$ & $45.70 \pm 1.12^{\mathrm{c}}$ & $38.47 \pm 1.44^{\mathrm{a}}$ & 0.000 \\
\hline Visceral mass & $24.48 \pm 1.97^{\mathrm{b}}$ & $23.94 \pm 1.44^{\mathrm{b}}$ & $19.81 \pm 2.78^{\mathrm{a}}$ & $20.44 \pm 2.64^{\mathrm{a}}$ & 0.009 \\
\hline
\end{tabular}

Table 3: Effects of dietary calcium level on the carcass proportions of Archachatina marginata.

a, b, c: On the same line, values affected withthe same letters are not significantly different ( $>0.05)$;

R1: Diet containing 12\% calcium; R2: Diet containing 14\% calcium; R3: Diet containing 16\% calcium; R4: Diet containing $18 \%$ calcium.

\begin{tabular}{|c|c|c|c|c|c|}
\hline \multirow{2}{*}{ Biochemical components (\%) } & \multicolumn{4}{|c|}{ Experimental Diets } & \multirow{2}{*}{$P$} \\
\hline & $\mathrm{R} 1(12 \% \mathrm{Ca})$ & $\mathrm{R} 2(14 \% \mathrm{Ca})$ & R3 (16\%Ca) & $\mathrm{R} 4(18 \% \mathrm{Ca})$ & \\
\hline Dry matter & $90.40 \pm 0.28$ & $90.59 \pm 0.27$ & $90.41 \pm 0.12$ & $90.50 \pm 0.17$ & 0.715 \\
\hline Organicmatter & $86.12 \pm 0.32 \mathrm{~b}$ & $86.15 \pm 0.35 b$ & $84.60 \pm 0.23 \mathrm{a}$ & $85.10 \pm 0.41 \mathrm{a}$ & 0.001 \\
\hline Proteins & $45.85 \pm 0.16 \mathrm{a}$ & $50.52 \pm 0.16 \mathrm{~b}$ & $55.22 \pm 0.26 \mathrm{c}$ & $57.30 \pm 0.34 \mathrm{~d}$ & 0.000 \\
\hline Fat & $3.73 \pm 0.25 b$ & $1.43 \pm 0.010 \mathrm{a}$ & $1.49 \pm 0.33 \mathrm{a}$ & $1.35 \pm 0.05 \mathrm{a}$ & 0.000 \\
\hline Carbohydrates & $36.52 \pm 0.087 \mathrm{~d}$ & $34.20 \pm 0.14 \mathrm{c}$ & $27.89 \pm 0.31 \mathrm{~b}$ & $26.44 \pm 0.39 \mathrm{a}$ & 0.000 \\
\hline Ash & $4.26 \pm 0.10 \mathrm{a}$ & $4.43 \pm 0.11 \mathrm{a}$ & $5.46 \pm 0.37 \mathrm{~b}$ & $5.38 \pm 0.33 b$ & 0.001 \\
\hline
\end{tabular}

Table 4: Effects of dietary calcium level on biochemical components of Archachatina marginata meat.

a, b, c: On the same line, values affected withthe same letters are not significantly different ( $>0.05)$;

R1: Diet containing 12\% calcium; R2: Diet containing 14\% calcium; R3: Diet containing $16 \%$ calcium; R4: Diet containing $18 \%$ calcium. 
Citation: Maël TF, Raphaël KJ, Ciza AP, Prisca MC, Paule DV (2019) Effects of dietary level of calcium on body proportion and nutritional value of African giant snail (Archachatina marginata). J Anim Res Vet Sci 3: 020.

\begin{tabular}{|c|c|c|c|c|c|}
\hline \multirow{2}{*}{ Mineral content in the meat (\%) } & \multicolumn{5}{|c|}{ Experimental Diets } \\
\cline { 2 - 6 } & $\mathrm{R} 1(12 \% \mathrm{Ca})$ & $\mathrm{R} 2(14 \% \mathrm{Ca})$ & $\mathrm{R} 3(16 \% \mathrm{Ca})$ & $\mathrm{R} 4(18 \% \mathrm{Ca})$ & \\
\hline $\mathrm{Ca}$ & $2.64 \pm 0.21^{\mathrm{a}}$ & $2.58 \pm 0.10^{\mathrm{a}}$ & $3.40 \pm 0.49^{\mathrm{b}}$ & $2.97 \pm 0.30^{\mathrm{ab}}$ & 0.042 \\
\hline $\mathrm{P}$ & $0.24 \pm 0.04^{\mathrm{ab}}$ & $0.20 \pm 0.02^{\mathrm{a}}$ & $0.23 \pm 0.023^{\mathrm{ab}}$ & $0.27 \pm 0.02^{\mathrm{b}}$ & 0.074 \\
\hline $\mathrm{K}$ & $0.22 \pm 0.017^{\mathrm{a}}$ & $0.21 \pm 0.020^{\mathrm{a}}$ & $0.21 \pm 0.04^{\mathrm{a}}$ & $0.36 \pm 0.015^{\mathrm{b}}$ & 0.000 \\
\hline $\mathrm{Mg}$ & $0.42 \pm 0.020^{\mathrm{a}}$ & $0.78 \pm 0.028^{\mathrm{c}}$ & $0.62 \pm 0.026^{\mathrm{b}}$ & $0.91 \pm 0.010^{\mathrm{d}}$ & 0.000 \\
\hline $\mathrm{Na}$ & $0.066 \pm 0.0057^{\mathrm{a}}$ & $0.066 \pm 0.015^{\mathrm{a}}$ & $0.077 \pm 0.0057^{\mathrm{a}}$ & $0.096 \pm 0.057^{\mathrm{b}}$ & 0.012 \\
\hline $\mathrm{Fe}$ & $0.037 \pm 0.005^{\mathrm{a}}$ & $0.067 \pm 0.005^{\mathrm{b}}$ & $0.083 \pm 0.005^{\mathrm{c}}$ & $0.066 \pm 0.01^{\mathrm{b}}$ & 0.000 \\
\hline
\end{tabular}

Table 5: Effects of calcium level in mineral content of Archachatina marginata meat.

a, b, c: On the same line, values affected withthe same letters are not significantly different ( $>0.05)$;

R1: Diet containing 12\% calcium; R2: Diet containing 14\% calcium; R3: Diet containing 16\% calcium; R4: Diet containing $18 \%$ calcium.

\begin{tabular}{|c|c|c|c|c|c|}
\hline \multirow{2}{*}{ Mineralscontent of shell (\%) } & \multicolumn{4}{|c|}{ Experimental Diets } & \multirow{2}{*}{$P$} \\
\hline & R1 (12\%Ca) & $\mathrm{R} 2(14 \% \mathrm{Ca})$ & R3 $(16 \% \mathrm{Ca})$ & $\mathrm{R} 4(18 \% \mathrm{Ca})$ & \\
\hline $\mathrm{Ca}$ & $22.54 \pm 0.12$ & $22.48 \pm 0.21$ & $22.59 \pm 0.61$ & $23.25 \pm 0.54$ & 0.176 \\
\hline K & $0.043 \pm 0.0057$ & $0.0367 \pm 0.011$ & $0.033 \pm 0.0057$ & $0.036 \pm 0.0057$ & 0.480 \\
\hline $\mathrm{Mg}$ & $0.91 \pm 0.015$ & $0.89 \pm 0.036$ & $0.92 \pm 0.020$ & $0.79 \pm 0.12$ & 0.129 \\
\hline $\mathrm{Na}$ & $0.020 \pm 0.00$ & $0.023 \pm 0.0057$ & $0.023 \pm 0.0057$ & $0.020 \pm 0.00$ & 0.596 \\
\hline $\mathrm{Fe}$ & $0.0010 \pm 0.0010$ & $0.0013 \pm 0.0015$ & $0.0013 \pm 0.0011$ & $0.0010 \pm 0.0010$ & 0.970 \\
\hline$P$ & Trace & Trace & Trace & Trace & - \\
\hline
\end{tabular}

Table 6: Effects of dietary calcium level on mineral content of Archachatina marginata shell.

\section{Discussion}

Feeding snails with a compounded balanced feed improved growth performance and nutritional value especially in calcium, protein, energy and vitamins $[2,4,16]$. The carcass proportion of Archachatina marginata as affected the level of dietary calcium show that the meat yield was higher $(45.70 \%)$ with $16 \%$ of calcium. The lowest proportion of soft tissue was recorded in snails fed on diet containing the highest calcium (18\%) and the soft tissue yield was observed to decrease with increasing calcium levels. This result agrees with the finding of Otchoumou [10] which state that weight and shell growth of snails are closely related to the content of certain nutrients such as calcium and protein. When calcium contentexceeds $16 \%$, this snail tends to develop much more shell than meat. The same phenomenon was reported by Ireland [17] on Achatina fulica and by Otchoumou [10] on Achatina achatina. In fact, the Pearson regression have shown that the increase in shell yield is closely related $\left(\mathrm{R}^{2}=0.975\right)$ to the increase in calcium level of the diet. The same tendency was observed with the variation in soft tissue yield that was closely related $\left(\mathrm{R}^{2}=\right.$ 0.982 ) to the increase in calcium level of the diet. The highest proportion of meat produced by snails in this study was $45.70 \%$ which is much higher than the $26.6 \%$ reported by Otchoumou et al., [7] in Achatina fulica, but not far from the proportions (42.2 to $43.97 \%$ ) obtained by Sika et al., [2] with the same species as well as the results (41.3\%) obtained by Kana et al., [4] with Archachatina marginata. These differences could be explained by the portion considered consumable in each study, the conditions of rearing and probably the live weight of the snail at slaughter. Fagbuaro [18] recorded a percentage of $41.18 \%$ by considering only the pedal mass (foot) of Archachatina marginata having a live weight of $324.13 \mathrm{~g}$. In the present study, the portion consisting of the foot, the head, the distal edge of the mantle bearing the last centimeter of the rectum and anus, the pneumostome, the pallial bead, and the distal part of the genital tract including thepenis sleeve, the anterior digestive tract to the first half of the crop were considered as edible as recommended by Aman [19].

This study also showed a variation in the chemical composition of the flesh of the snails as affected by the calcium level of the diet. Snail's meat fed on $18 \%$ calcium is richer in protein $(57.30 \%)$ than snails fed on the other three rations, with the lowest content of protein $(45.85 \%)$ being recorded with the lowest calcium level (12\%). The same trend was recorded with the ash content of meat suggesting that the biochemical composition of snails depend on thecomposition of diet consumed [2]. In fact, the Pearson regressions show that the increase in the protein content of snail meat depends strongly $\left(\mathrm{R}^{2}=\right.$ 0.995 ) on the calcium level of the ration. The protein content of snail flesh increases linearly with the increasing rate of calcium in the diet. Many authors noticed the importance of calcium in improving the biological performance of farmed snails [10,16,20-22,]. Several studies also reported the synergistic action of mineral elements andorganic matter such as proteins on growth and even reproduction of snails [23]. Thus, we can note the presence of other minerals such as magnesium, which is essential for the assimilation of vitamin B2 (Thianine), essential for protein synthesis, carbohydrate metabolism and would also facilitate the absorption of calcium and phosphorus [24]. Sika et al., [2] revealed that the snails' meat is enriched with the protein of diet that they consumed. These observations corroborate the findings of Kana et al., [4] on Archachatina marginata.

The higher lipid content was recorded with the lowest calcium level $(12 \%)$ and the lowest $(1.35 \%)$ with the highest calcium level $(18 \%)$. Similarly, the meat of snails fed on the smallest calcium (12\%) was richer in carbohydrates $(36.52 \%)$ which decrease linearly with the increasing rate of calcium in the diet. The chemical composition of snail meat varies with species, breeding conditions and many other factors. Indeed, Kouadio et al., [25] studied some of the growth 
and nutritional value parameters of two wild-grown varieties of Archachatina marginata snail. The results showed that the flesh had a protein level of $62.66 \%$; fat content of $2.98 \%$; and total carbohydrates of $4.29 \%$. The values recorded in the present study are much higher than those obtained by Fagbuaro [18] who reported 1.36\%; 4.27\%; $14.48 \%$; and $0.78 \%$ for ashes, fat, crude protein, and total sugars respectively. The present crude protein is also higher than the values of $20.50 ; 25.68$ and $48.85 \%$ respectively recorded by Fagbuaro et al., Adeola et al., and Sea et al., [5,26,27] . These differences could be explained on one hand by the potentially different genetic characteristics of the strains used by each of the authors because of the existence of several subspecies not yet identified [28] and on the other hand, by the experimental conditions and techniques.

Regarding the mineral analysis, it appears that the meat of the snails fed on diet containing $16 \%$ calcium is richer in calcium $(3.40 \%)$ than that of the snails fed on three other rations. and the lowest calcium content $(2.58 \%)$ was recorded with the ration containing $14 \%$ calcium. This study also revealed that, the most important mineral element in the flesh of snails is calcium. Kouadio et al., [25] revealed that, particularly with regard to calcium, its rate is higher in the white-fleshed variety $(20.34 \%)$ than in the black flesh $(17.38 \%)$ of Archachatina marginata grown in the wild. These calcium levels recorded from different varieties of $A$. marginata are higher than the value recorded in this study and also higher than the values estimated in the flesh of snails of the same species fed by different nitrogen sources as reported by Ademolu et al., [29]. The amount of calcium is estimated in this different flesh between 46.75 and $941.75 \mathrm{mg} / 100 \mathrm{~g}$ of dry matter. In the present study, the highest mineral values were recorded with $18 \%$ calcium in the diet while the highest iron level (0.083) was recorded with $16 \%$ calcium. All these minerals were also found in the flesh of the wild-caught Archachatina marginata snails [25] and Helix promatia [30] harvested in southern Turkey [31]. With regard to iron, the rate is lower in the flesh of the snails studied in the present research $(0.037-0.083 \%)$ compared to the rate of $0.09 \%$ reported by Kouadio et al., [25] in the same species. These values are much higher than those recorded by Sea et al., [27] in Limicolaria flammae.

Calcium is the most abundant mineral with a higher rate recorded in snails fed on $18 \%$ calcium. This result is in agreement with other studies [28], which showed that calcium is the essential mineral in the shell of the snail. However, the calcium content recorded in the present study is lower than the valuerecorded by Kouadio et al., [25] in the same species (35.34\%). Similar results were recorded with Archachatina ventricosa (36.84\%), Achatina achatina [32] (36.13\%) and Achatina fulica (36.86\%). The high calcium content of the $A$. marginata shell may justify its utilization as a calcium source in animal feed formulations. Indeed, snail shell powder can be used in animal feeds such as broilers and layers [11].

\section{Conclusion}

This study revealed that calcium is one of the essential nutrients to be considered in snail production. Increasing calcium content in the ration improves growth, carcass yield and nutritional value of $A$. marginata. Definitely, the calcium need for better meat proportion and nutritional value of $A$. marginata is $16 \%$ in ration.

\section{Conflict of Interest}

We declare that we have no financial and personal relationships with other people or organizations that can inappropriately influence our work; there is no professional or other personal interest of any nature or kind in any product, service and/or company that could be construed as influencing the content of this paper.

\section{References}

1. Bouye TR, Ocho-anin AA, Karamoko M et Otchoumou A (2017) Étude de la croissance d'un escargot géant africain comestible : Achatina achatina (Linné, 1758), élevé sur du substrat amendé à la poudre de coquilles d'escargot. Journal of Applied Biosciences 109: 10630-10639.

2. Sika PNA, Karamoko M, Adou CFD, Otchoumou A, Kouassi PK (2014) Effet du régime et de la teneur en protéines brutes alimentaires sur le rendement en viande de l'escargot Achatina fulica (Bowdich, 1720). International Journal of Biological and Chemical Sciences 5: 2296-2305.

3. Okon B, Ibom LA, Ina-Ibor OB, Owai PU (2016) Nutritional evaluation of giant african land snail (Archachatina marginata var. saturalis) fed diet containing full fat rubber as a replacement for soybean. Nigerian Journal of Agriculture, Food and Environment 2: 1-8.

4. Kana JR, Tchakounte FM, Meffowoet CP (2018) Effets du régime alimentaire sur la croissance et la valeur nutritive de la viande d'escargots géants africains Archatina marginata. Livestock Research for Rural Development 3: $1-10$.

5. Fagbuaro O, Oso JA, Edward JB, Ogunleye RF (2006) Nutritional status of four species of giant land snails in Nigeria. J Zhejiang Univ Sci B 7: 686-689.

6. Diomandé M, Kipré AV, Koussemon M, Kamenan A (2008) Substitution de la farine de poisson par celle de l'escargot (Achatina fulica) dans l'alimentation des poules pondeuses en Côte d' Ivoire. Livestock Research for Rural Development 1: 23-27.

7. Otchoumou A, Dupont-Nivet M, Ocho A, Atchibri L, Dosso H (2010) Body proportions and chemical composition of wild and reared edible snails of Ivory Coast. Italian Journal of Food Science 1: 1120-1770.

8. Narku EF, Akowuah AN, Owusu DP, Sefah W (2013) Proximate and Mineral Composition of Snail (Achatina achatina) Meat; Any Nutritional Justification for Acclaimed Health Benefits. Journal of Basic and Applied Scientific Research 4: 8-15.

9. Sami AS, Augustini C, Schwars FJ (2004) Effects of feeding intensity and time on feed on performance, carcass characteristics and meat quality of Simmental bulls. Meat Sciences 67: 195-201.

10. Otchoumou A (2005) Effet de la teneur en calcium d'aliments composés et de la photopériode sur les performancesbiologiques chez trois espèces d'escargots Achatinidae de Côte d'Ivoire élevées en bâtiment. Thèse de Doctorat d'Etatès-Sciences Naturelles en Biologie et Ecologie Animales, Université d'Abobo-Adjamé, Abidjan-Côte d'Ivoire Pg No : 171.

11. Houndounongbo MF, Chrysostome CAAM, Odoulami CR, Codjia JTC (2013) Valorisation des coquilles d'escargot dans l'alimentation des poules pondeuses: Taux optimal et mode de distribution. Dixième Journée de la Recherche Avicole et Palmipèdes à Foie Gras. La Rochelle du 26 au 28 mars 2013. 911-916.

12. Kouakou BKT, Kouassi KD, Kouadio YJ (2014) Management of shells of giant African snail (Achatinidae) from the markets of Abidjan (Côte d'Ivoire). Journal of Applied Biosciences. 83: 7625-7635.

13. Sika PNA, Karamoko M, Bouye TR, Otchoumou A, Kouassi KP (2015) Effet du régime et de la teneur en protéines brutes alimentaires sur le rendement en viande de l'escargot Achatina fulica (Bowdich, 1720). International Journal of Innovation and Applied Studies 1: 85-93. 
14. Otchoumou A, Dosso H, Fantodji A (2003) The edible African giant snails: Fertility of Achatina achatina (Linné, 1758), Achatina fulica (Bodwich, 1820) and Archachatina ventricosa (Gould, 1850) in humid forest influence of animal density and photoperiod on the fertility in breeding. Bollettino Malacologico 39: 179-184.

15. Narku EF, Akowuah AN, Owusu DP, Sefah W (2013) Proximate and Mineral Composition of Snail (Achatina achatina) Meat; Any Nutritional Justification for Acclaimed Health Benefits. Journal of Basic and Applied Scientific Research 4: 8-15.

16. Karamoko M, Sika NA, Adou CFD, Otchoumou A, Kouassi KP (2015) Effets du calcium alimentaire sur les paramètres de croissance de l'escargot Limicolaria flammea (Müller, 1774), en élevage hors-sol. International Journal of Innovation and Applied Studies 1: 231-240.

17. Ireland MP (1991) The effect of dietary calcium on growth, shell thickness and tissue calcium distribution in the snail Achatina fulica. Comparative Biochemestry and Physiology 1: 111-116.

18. Fagbuaro SS (2015) Carcass characteristics, proximate composition and mineral analysis of African giant snail (Archachantina marginata). ECORFAN Journal-Mexico 14: 2235-2242.

19. Aman JB (2013) Effet de la source et de la teneur en calcium du substrat d'élevage sur les performances biologiques d'Archachatina marginata (Swainson, 1821). Thèse de Doctorat unique en Biologie et Productions Animales, UFR des Sciences de la Nature, Université Nangui Abrogoua, Abidjan Côte d'Ivoire Pg No : 156.

20. Zongo D, Coulibaly M, Diambra OH, Adjiri E (1990) Note sur l'élevage de l'escargot géant africain Achatina achatina Nature et Faune 6: 32-44.

21. Codjia JTC (2001) Alimentation et croissance des escargots géants africains Archachatina (Calachatina) marginata (Swainson) et Achatina fulica Bowdich, en captivité. Anales des Sciences Agronomiques du Bénin 2: 141-152.

22. Kouassi KD, Otchoumou A, Dosso H (2007) Effets de l'alimentation sur les performances biologiques chez l'escargot géant africain: Archachatina ventricosa (Gould 1850) en élevage hors-sol. Livestock Research for Rural Development 5: 16-20.
23. Cobbinah JC, Adri V, Onwuka B (2008) L'élevage des escargots: Production, transformation commercialisation. Agromisa/CTA, Wageningen Netherlands.

24. Parigi BR (1986) Les bases de l'alimentation du bétail. Padoue Nella Litografia Felici Spartaco 292.

25. Kouadio EJP, Konan KH, Brou K, Dabonné S, Dué AE et al. (2015) Etudes de quelques paramètres de croissance et de valeur nutritive des variétés d'escargot Archachatina marginata (Swainson) élevées en milieu naturel. Tropicultura 1: 3845 .

26. Adeola AJ, Adeyemo AI, Ogunjobi JA, Alaye SA, Adelakun KM (2010) Effects of natural and concentrate diets on proximate composition and sensory properties of giant landsnail (Archachatina marginata) meat. Journal of Applied Sciences in Environmental Sanitation 2: 185-189.

27. Sea BT, Saki JS, Golly JK, Kra S, Soro RY, et al. (2008) Caractérisation de la chair de l'escargot Limicolaria flammea. Revue Ivoirienne des Sciences Technologiques 11: 83-90

28. Hardouin J, Steivenart C, Codjia JTC (1995) L'Achatiniculture. Revue mondiale de Zootechnie. 2: 29-39.

29. Ademolu KO, Idowu AB, Mafiana CF, Osinowo OA (2004) Performance, proximate and mineral analyses of African giant land snail (Archachatina marginata) fed different nitrogen sources. African Journal of Biotechnology 8: 412-417.

30. Bonnet JC, Aupinel et Vrillon JL (1990) L'escargot Helix aspersa: Biologieélevage. Jean-Louis Vrillon, INRA Editeur, Paris.

31. Özogul Y, Özogul F, Olgunoglu AI (2005) Fatty acid profile and minera content of the wild snail (Helix pomatia) from the region of the south of the Turkey, European Food Research and Technology 221: 547549.

32. Kouassi KD, Otchoumou A, Gnakri D (2008) Le commerce des escargots (Achatina achatina), une activité lucrative en Côte d'Ivoire. Livestock Research for Rural Development 20 


\section{Hit \\ HERALD}

Journal of Anesthesia \& Clinical Care

Journal of Addiction \& Addictive Disorders

Advances in Microbiology Research

Advances in Industrial Biotechnology

Journal of Agronomy \& Agricultural Science

Journal of AIDS Clinical Research \& STDs

Journal of Alcoholism, Drug Abuse \& Substance Dependence

Journal of Allergy Disorders \& Therapy

Journal of Alternative, Complementary \& Integrative Medicine

Journal of Alzheimer's \& Neurodegenerative Diseases

Journal of Angiology \& Vascular Surgery

Journal of Animal Research \& Veterinary Science

Archives of Zoological Studies

Archives of Urology

Journal of Atmospheric \& Earth-Sciences

Journal of Aquaculture \& Fisheries

Journal of Biotech Research \& Biochemistry

Journal of Brain \& Neuroscience Research

Journal of Cancer Biology \& Treatment

Journal of Cardiology: Study \& Research

Journal of Cell Biology \& Cell Metabolism

Journal of Clinical Dermatology \& Therapy

Journal of Clinical Immunology \& Immunotherapy

Journal of Clinical Studies \& Medical Case Reports

Journal of Community Medicine \& Public Health Care

Current Trends: Medical \& Biological Engineering

Journal of Cytology \& Tissue Biology

Journal of Dentistry: Oral Health \& Cosmesis

Journal of Diabetes \& Metabolic Disorders

Journal of Dairy Research \& Technology

Journal of Emergency Medicine Trauma \& Surgical Care

Journal of Environmental Science: Current Research

Journal of Food Science \& Nutrition

Journal of Forensic, Legal \& Investigative Sciences

Journal of Gastroenterology \& Hepatology Research

Journal of Gerontology \& Geriatric Medicine

Journal of Genetics \& Genomic Sciences

Journal of Hematology, Blood Transfusion \& Disorders

Journal of Human Endocrinology

Journal of Hospice \& Palliative Medical Care

Journal of Internal Medicine \& Primary Healthcare

Journal of Infectious \& Non Infectious Diseases

Journal of Light \& Laser: Current Trends

Journal of Modern Chemical Sciences

Journal of Medicine: Study \& Research

Journal of Nanotechnology: Nanomedicine \& Nanobiotechnology

Journal of Neonatology \& Clinical Pediatrics

Journal of Nephrology \& Renal Therapy

Journal of Non Invasive Vascular Investigation

Journal of Nuclear Medicine, Radiology \& Radiation Therapy

Journal of Obesity \& Weight Loss

Journal of Orthopedic Research \& Physiotherapy

Journal of Otolaryngology, Head \& Neck Surgery

Journal of Protein Research \& Bioinformatics

Journal of Pathology Clinical \& Medical Research

Journal of Pharmacology, Pharmaceutics \& Pharmacovigilance

Journal of Physical Medicine, Rehabilitation \& Disabilities

Journal of Plant Science: Current Research

Journal of Psychiatry, Depression \& Anxiety

Journal of Pulmonary Medicine \& Respiratory Research

Journal of Practical \& Professional Nursing

Journal of Reproductive Medicine, Gynaecology \& Obstetrics

Journal of Stem Cells Research, Development \& Therapy

Journal of Surgery: Current Trends \& Innovations

Journal of Toxicology: Current Research

Journal of Translational Science and Research

Trends in Anatomy \& Physiology

Journal of Vaccines Research \& Vaccination

Journal of Virology \& Antivirals

Archives of Surgery and Surgical Education

Sports Medicine and Injury Care Journal

International Journal of Case Reports and Therapeutic Studies 